\title{
Evaluation of house flap anoplasty in cicatricial anal stenosis
}

\author{
Hany Mohamed El-Barbary, MD, FRCSI* \\ Department of General Surgery, Ain Shams University, Cairo, Egypt
}

*(Presented in the 11th congress of the Egyptian Group of Colorectal Surgeons, Sharm ElSheikh, June-2009)

\begin{abstract}
Anal stenosis is a rare but incapacitating and challenging condition, occurring mainly after hemorrhoidectomy.

Both non-surgical and surgical treatments have been described for the treatment of anal stenosis. Moreover, several surgical techniques have been devised for treatment of this condition but none proved ideal for all patients.

Patients and methods: We advocated the "house advancement flap" anoplasty in Ain Shams University, Departement of Surgery in nine patients and evaluated the postoperative outcome as regards symptom relief, and late complications.

Results: Post hemorroidectomy anal stenosis was the most common cause ( $n=6$ out of 9 patients $=67 \%)$. Postoperative complications included donor-site separation (1), urinary retention (1) and sepsis (3). At a median follow-up of 6 months, 7 out of 9 patients were completely satisfied and 2 improved. Of these, one patient had multiple flaps done (2) to improve outcome.

To conclude: House flap anoplasty is simple and can be used to correct many anoderm deficiencies with a high rate of success and patient satisfaction.
\end{abstract}

\section{Introduction:}

Anal stenosis by definition is an abnormal narrowing of the anal canal to a varying extent due to stricture of the epithelial lining that has been replaced by fibrous scar formation, which results in a reduced lumen and particularly loss of the capacity to dilate with passage of stools, resulting into passage of ribbon-like feces and constipation. ${ }^{1}$

Indications for anoplasty include: anal stenosis, anal ectropion, Bowen's disease, keyhole deformity and perineal fistula. ${ }^{2}$

Postoperative anal stenosis is a serious complication of anal operations. To date, ideal management of this problem has not been well defined. Causes include: Post hemorrhoidectomy, anorectal surgical procedures associated with inflammatory bowel diseases ${ }^{3}$ or surgical procedures carried out overzealously without the required technical knowledge Table(1).1 By far, haemorrhoidectomy is the most common cause of anal stenosis accounting for more than $75 \%$ of cases. ${ }^{4}$

\section{Table(1): Etiology of Anal Stenosis.}

1. Hemorrhoidectomy
2. Laxative abuse
3. Fissurectomy
4. Fistulectomy
5. Excision and electrocoagulation of
$\quad$ condyloma
6. Correction of congenital malformation
7. Debridement after e.g.: Fournier's gangrene

Several techniques have been described for treatment of anal stenosis Figure(1), which allow delivery of the more pliable anoderm into the anal canal to replace the scarred lining at that level. No technique has been proven satisfactory for all patients. ${ }^{5}$ 
A

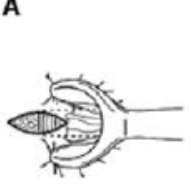

B
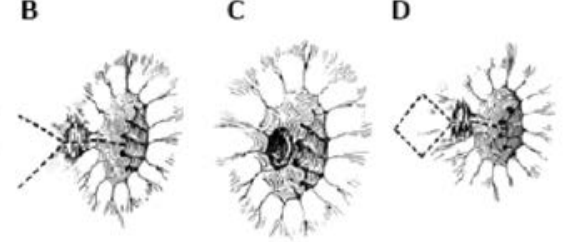

E
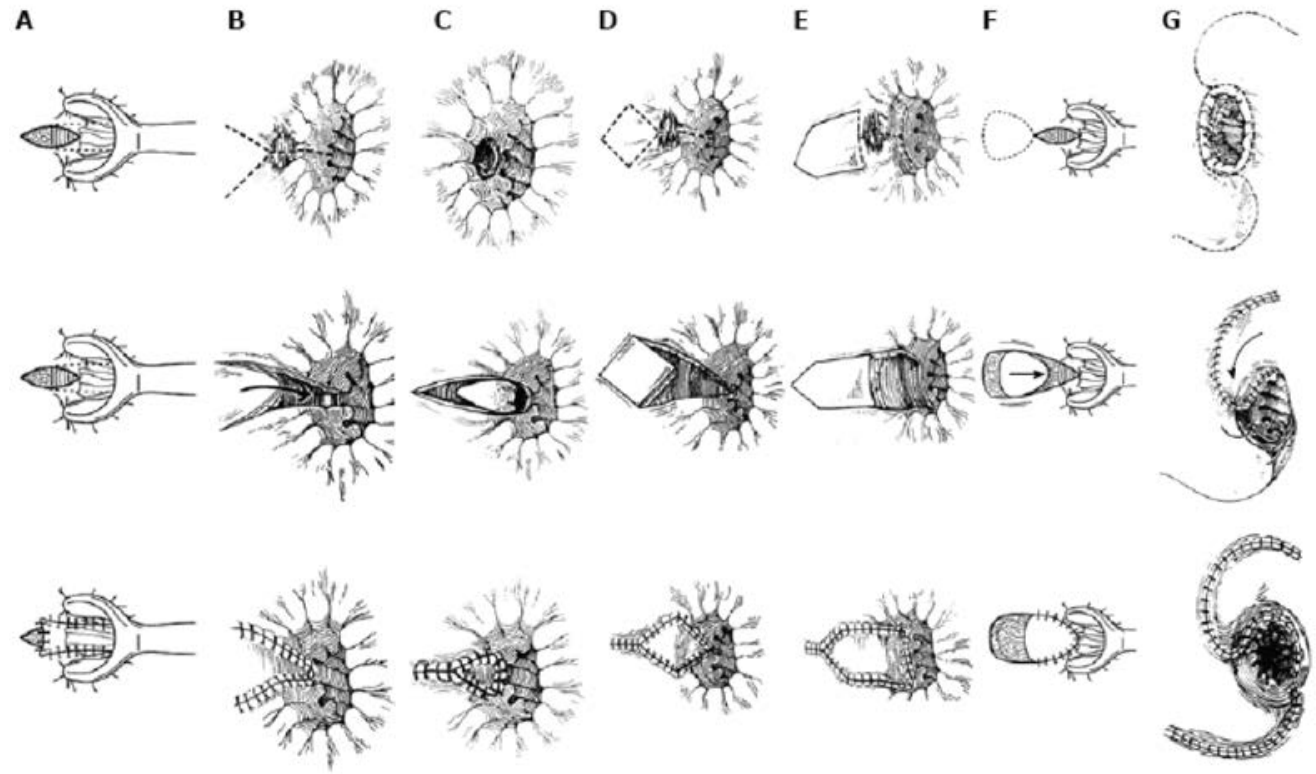

Figure (1): Operative procedure for the surgical treatment of anal stenosis. A: Martin's anoplasty; $B: Y-V$ advancement flap; $C: V-Y$ advancement flap; $D:$ Diamond-shaped flap; E: House-shaped flap; F: U-shaped flap; G: Rotational S-flap.

\section{Aim of the study:}

Prospective evaluation of the "house advancement flap" anoplasty advocated in Departement of Surgery, Ain Shams University, regarding postoperative outcome;

1. Symptomatic relief

2. Early \& late complications

\section{Patients and methods:}

This is a prospective case series of patients admitted with diagnosis of anal stenosis (AS) seen in the period from January 2006 to February 2009.

\section{Inclusion criteria:}

$>$ Patients who failed to respond or refuse conservative medical treatment; stool softeners, anal dilatation ... etc,

$>$ Moderate to severe degree AS.

We advocated the "house advancement flap anoplasty" in all patients as a short stay procedure and followed the patients clinically after discharge one week later and after one month and up to 6 months. Interval visits were arranged accordingly as needed to manage any complications. Preoperatively, no bowel preparation is needed, but a prophylactic dose of antibiotic is given.

\section{Surgical technique:}

1 - The patient is positioned in the lithotomy position after anesthesia, general or regional. Skin preparation should include the ipsilateral gluteal area as far as the graft may be taken. Usually inspection and P/R is done which will reveal the extent of stenosis Figure(2).

2- Drawing of the flap is done with skin marker which should take into consideration the extent of scar tissue excised Figure(3).

3 - The flap is dissected and shaped like a house using the electrocautery at low power; the base corresponds to the width of the new anoderm, i.e. the amount of anal circumferential widening; the side walls correspond to the length of the defect after excision of the scarred tissue and the tapering roof corresponds to the degree of mobilization needed to move a vascularised pedicle of skin and subcutaneous tissue inside the anal canal with minimal tension and at the same time allowing primary closure of the donor site. Sphincterotomy may be needed to widen the canal and help mobilization Figure(4-6).

4- After full mobilization and haemostasis, the flap is sutured with $3 / 0$ vicryl® starting at the inner cut edge of the anoderm in the widened anal canal, proceeding laterally and then closing the donor site, all with interrupted sutures and no drains or anal packs are left. Light dressing is done to cover the wound Figure(7-9). 
Operative photos of a case of severe anal stenosis:

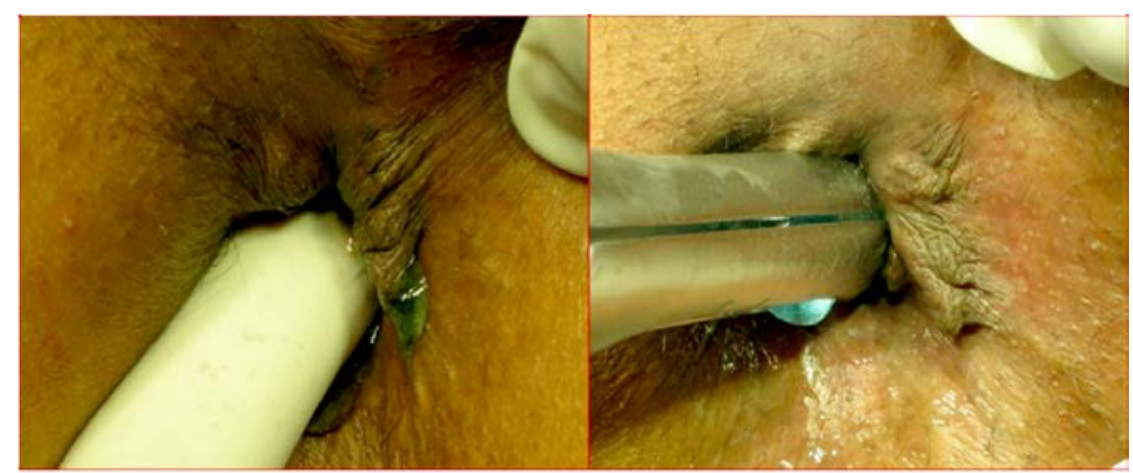

Figure (2): P/R almost impossible Can't open retractor.
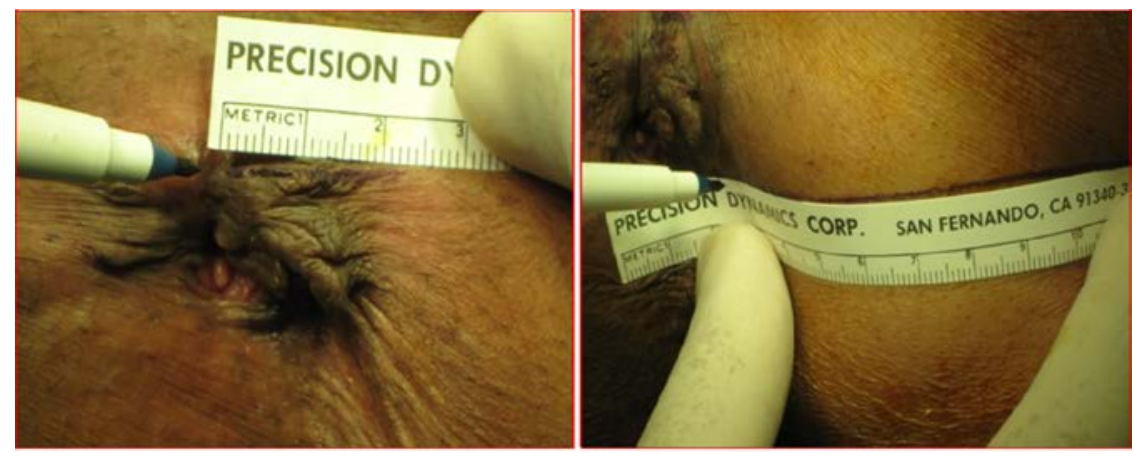

Figure (3): Measuring length of scar

Drawing the flap.
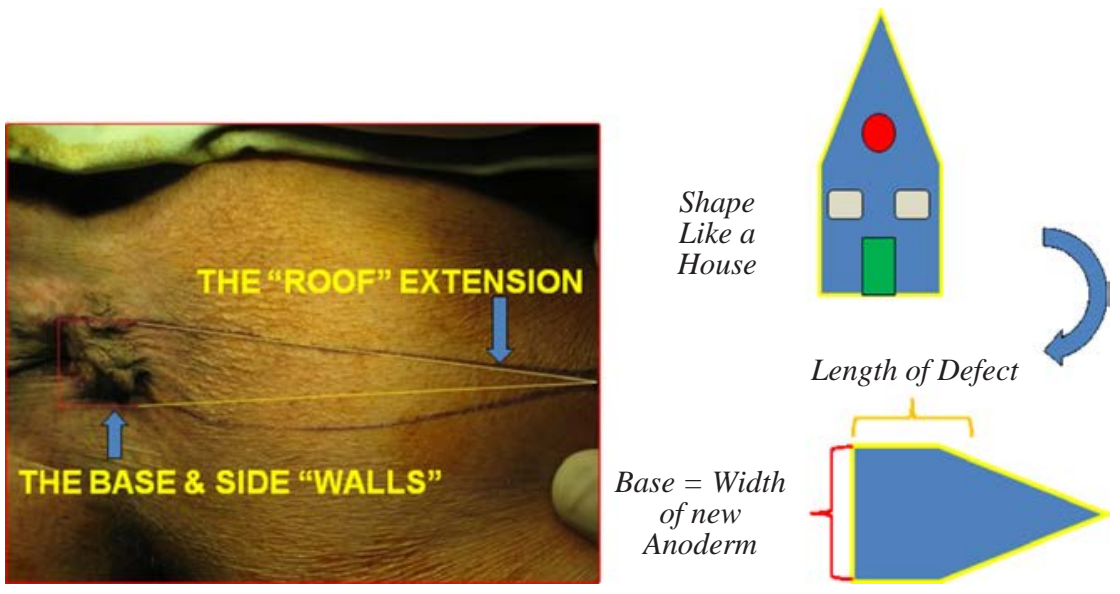

Figure (4)

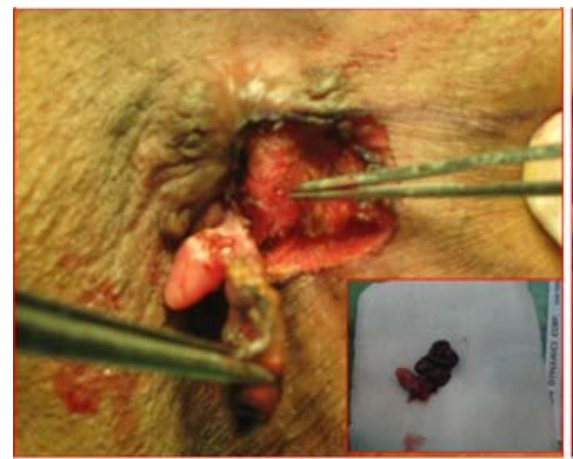

Figure (5): Exision of scar tissue

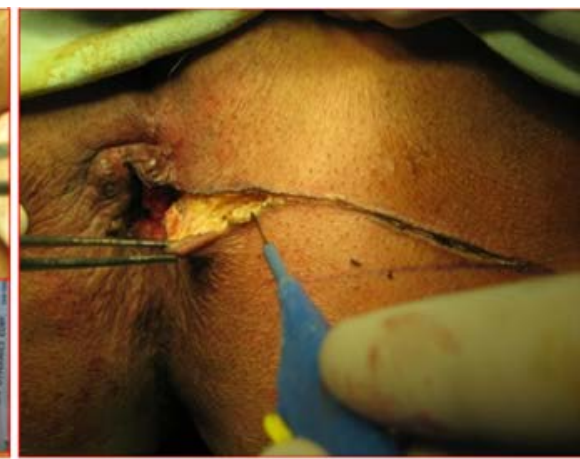

Dissection of flap. 


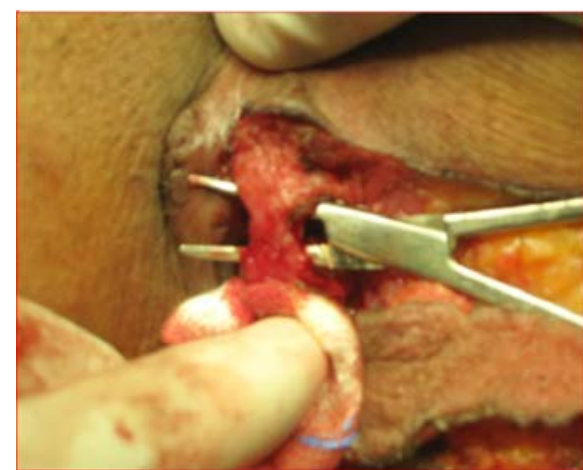

Figure (6): Sphincterotomy

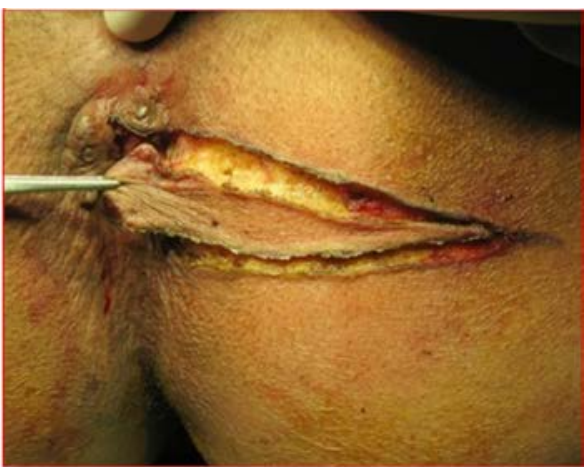

Flap mobilization.

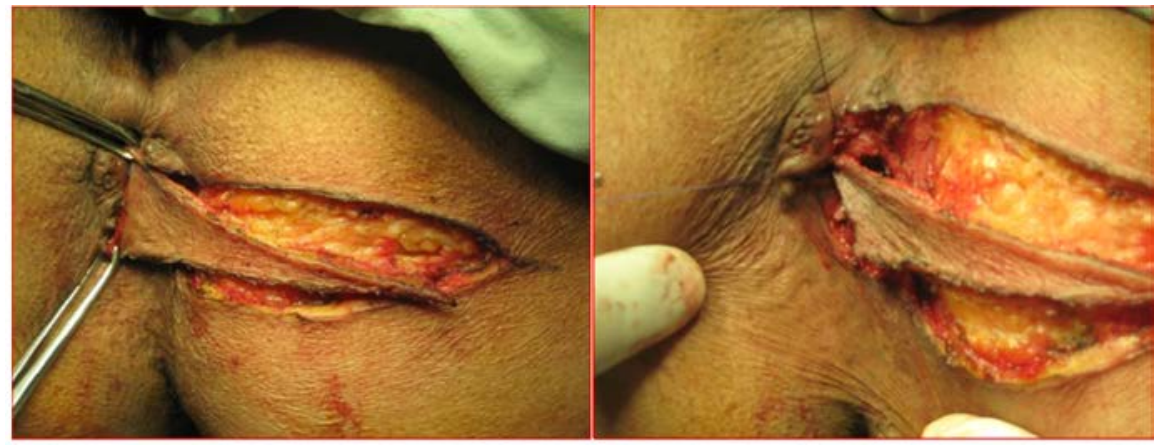

Figure (7): Advancement completed Suturing inner side.

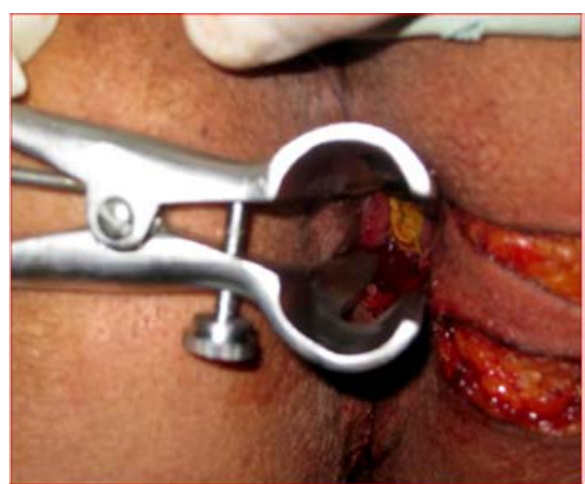

Figure (8): The anus widenned

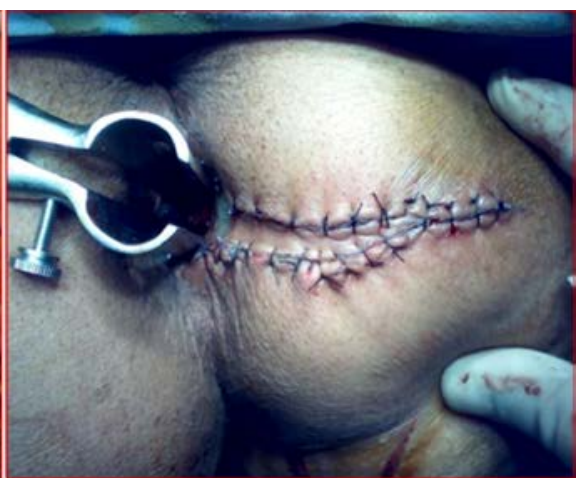

Donor site closed.

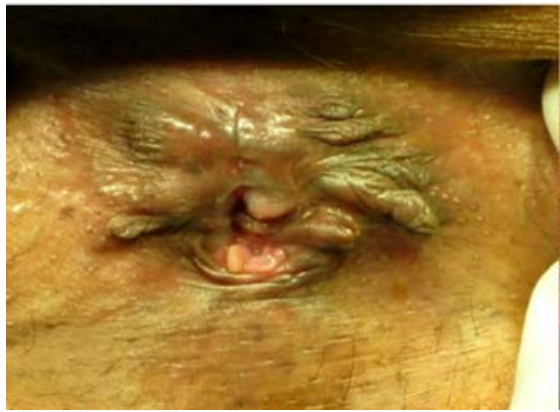

Figure (9): Before

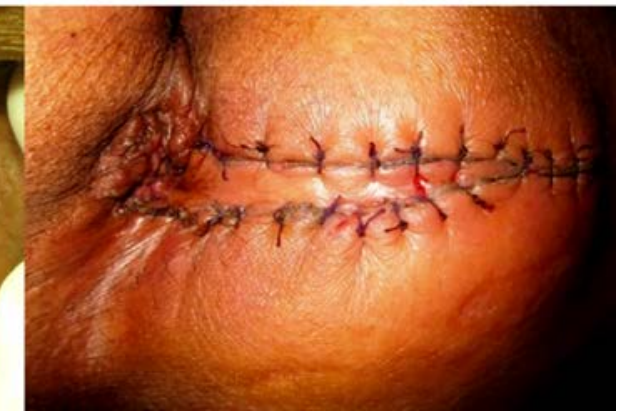

After

This is a comparative photo between the condition immediately preop. and before discharge (2nd day postop.) of the same patient. 


\section{Postoperatively:}

Patients are kept on normal diet, regular sitz baths and antibiotics in the form of a second generation cephalosporin and metronidazole $500 \mathrm{mg}$ tabs tds for three to five days. All patients are sent home usually after the 1st or 2 nd postoperative day. The 1st office visit is scheduled after 7 days to detect early complications. Follow up for 6 months is done for all patients to detect late results and/or complications.

\section{Results:}

There were nine patients in this series $(n=9)$; 4 Males and 5 Females with a median age of 39 (21-57). Post hemorroidectomy anal stenosis was the most common cause ( $n=6$ out of 9 patients $=67 \%$ ). Other causes included: Post fissurectomy $(\mathrm{n}=1) \&$ post fistulectomy $(\mathrm{n}=2)$.

The degree of stenosis was ranging from: Moderate 6 (requiring forcefull dilatation by $\mathrm{P} / \mathrm{R})$, severe 3 (P/R impossible), of which one had 2 flaps. This was based on clinical assessment and patient symptoms.

On the other hand, the level of anal stenosis was noted as follows: Five low strictures (below the dentate line), 3 middle (reaching the dentate line) and 1 high (reaching above the dentate line).
OR time: median $25 \min (27-73 \mathrm{~min})$.

Hospital stay: (median 2 days)

Postoperative complications included:

1. Donor-site separation $(\mathrm{n}=1,11 \%)$, healed in 2 weeks by 2 ry intention.

2. Urinary retention $(n=1,11 \%)$, relieved by single dose of analgesic NSAID.

3. Moderate perianal sepsis $(n=3,33 \%)$, controlled by local care, patients were diabetics.

At a median follow-up of 6 months, 7 out of 9 patients were completely satisfied (78\%) and 2 improved with no restenosis. Of these, one patient with very tight anus had multiple flaps done (twice) to improve outcome.

\section{Discussion:}

Anal stenosis is a rare but incapacitating, and challenging condition, occurring mainly after hemorrhoidectomy. ${ }^{1}$ Both non-surgical and surgical treatments have been devised for the treatment of anal stenosis. Moreover, several surgical techniques have been devised for treatment of this condition but none proved ideal for all patients ${ }^{4}$ Table(2).

Table (2): Different case series of anoplasties in the literature with results. ${ }^{1}$

\begin{tabular}{|c|c|c|c|c|}
\hline Author, year & Technique & Number of cases & Mean Follow-up (months) & Good results \\
\hline Gonzalez et al.,' 1995 & S-plasty and adyancement flaps & 17 & 18 & $94 \%$ \\
\hline Sarner, ${ }^{6} 1969$ & Samer's flap & 21 & $\mathrm{Nr}$ & $100 \%$ \\
\hline Oh \& Zinberg, 1982 & C-plasty & 12 & 12 & $92 \%$ \\
\hline Khubchandani, ${ }^{10} 1985$ & Mucosal flap & 53 & $\mathrm{Ne}_{\mathrm{f}}$ & $94.1 \%$ \\
\hline Gingold \& Arvanitis," 1986 & Y.V & 14 & $\mathrm{Nr}$ & $100 \%$ \\
\hline Milson \& Mazier, ${ }^{12} 1986$ & Y.Y (1) and Samer's (2) flap & 24 & Minimum: 1 & $90 \%(1) 75 \%(2)$ \\
\hline Caplin \& Kodner, ${ }^{13} 1986$ & Diamond flap & 7 & $\mathrm{Nr}$ & $100 \%$ \\
\hline Pearl et al, $1990^{15}$ & Island flaps (U or diamond) & 25 & 19 & $92 \%$ \\
\hline Habr-Gama et al., $1991^{16}$ & Sarner's and Musiari's flaps & 61 & 19 & $92 \%$ \\
\hline Angelchik et al., 199317 & Y.V anoplasty or diamond flap & 14 & 12 & $100 \%$ \\
\hline Pidala et al., 1994" & Island flap & 28 & 36 & $91 \%$ \\
\hline Sentovich et al., 1996" & House flap & 21 & 28 & $90 \%$ \\
\hline Medeiros, $1997^{20}$ & Samer's flap & 30 & $\mathrm{Nr}$ & $100 \%$ \\
\hline Maria et al., 199821 & Y.V anoplasty or diamond flap & 42 & 24 & $93 \%$ \\
\hline Ralkhmanine et al., $2002^{2}$ & Mucosal flap & 95 & 50 & $90 \%$ \\
\hline
\end{tabular}

Nr: not repoted 
The ideal management of this problem has not been well defined. ${ }^{3}$ Milsom and Mazier in 1986, on the basis of severity, distinguished mild (tight anal canal can be examinated by a well-lubricated index finger or a medium HillFerguson retractor), moderate (forceful dilatation is required to insert either the index finger or a medium Hill-Ferguson retractor) and severe anal stenosis (neither the little finger nor a small Hill-Ferguson retractor can be inserted unless a forceful dilatation is employed). On the other hand, on the basis of topography, stenosis may be diaphragmatic (after inflammatory bowel disease, characterized by a thin strip of constrictor tissue), ring-like or anular (after surgical or traumatic lesions, of length less than $2 \mathrm{~cm}$ ) and tubular (length more than $2 \mathrm{~cm}$ ). On the basis of the anal canal levels, stenosis may also be distinguished as low stenosis (distal anal canal at least $0.5 \mathrm{~cm}$ below the dentate line, $65 \%$ of patients), middle $(0.5 \mathrm{~cm}$ proximal to $0.5 \mathrm{~cm}$ distal to the dentate line, $18.5 \%$ ), high (proximal to $0.5 \mathrm{~cm}$ above the dentate line, $8.5 \%$ ) and diffuse (all anal canal, 6.5\% of cases). 5

Mild anal stenosis can be managed conservatively with stool softeners or fiber supplements. Sphincterotomy may be quite adequate for a patient with a mild degree of narrowing. For more severe stenosis, a formal anoplasty should be performed to treat the loss of anal canal tissue. 5
In our study, at Ain Shams Faculty of Medicine, we advocated the "house advancement flap" anoplasty in all patients as a short stay procedure and followed the patients clinically after one week of discharge then after one month and after six months to evaluate its short term outcome, patient satisfaction and complications and/or restenosis.

House advancement flap is a technique described to relieve an anal stenosis that involves the entire circumference and length of the anal canal from the dentate line onto the perianal skin. It has two principal advantages: 1) It provides a broad skin flap for the entire length of the involved anal canal; 2) It provides primary closure of the donor site; 3 ) It avoids extensive mobilization of tissue; 4) The flap maintains good blood supply with minimal tension, and there is no small tip prone to necrosis. ${ }^{6}$ This is shown in Table(3). In our study, "house advancement flap" anoplasty proved to be a simple technique to learn, teach and execute. It proved effective in intermediate \& severe grades of AS. Because it avoids angles of ischemia in the graft with a wide base that immediately widens the anal opening, it gave good symptomatic relief. Donor sites were closed primarily with no evidence of flap necrosis. Furthermore, this technique could be repeated in different quadrants for maximum results. We had it in one patient. It was effective in long strictures of the anal canal extending from the dentate line to the perianal skin, as stated by Christensen et al. ${ }^{6}$ It had minimal containable side effects. Short term and long term results were encouraging. 
Table (3): Advantages and indications of house flap anoplasty 5

\begin{tabular}{|c|c|c|}
\hline Procedures & Indications & Advantages/Disadvantages \\
\hline $\begin{array}{l}\text { Partial lateral } \\
\text { internal } \\
\text { sphincterotomy }\end{array}$ & $\begin{array}{l}\text { Functional stenosis, mild and low } \\
\text { stricture in the anal canal }\end{array}$ & $\begin{array}{l}\text { This technique is simple and safe. } \\
\text { Use is limited to functional stenosis }\end{array}$ \\
\hline $\begin{array}{l}\text { Mucosal } \\
\text { advancement } \\
\text { flap }\end{array}$ & Middle or high localized stricture & $\begin{array}{l}\text { Ectropion formation if the flap is } \\
\text { sutured at the anal verge }\end{array}$ \\
\hline $\begin{array}{l}\text { Y-V advancement } \\
\text { flap }\end{array}$ & $\begin{array}{l}\text { Low and localized stricture below } \\
\text { the dentate line }\end{array}$ & $\begin{array}{l}\text { Proximal part of the flap is very } \\
\text { narrow and will not allow for a } \\
\text { significant widening of the stricture } \\
\text { above the dentate line. Also,the tip } \\
\text { of the } V \text { within the anal canal is } \\
\text { subject to ischemic necrosis from } \\
\text { lack of mobilization, tension of the } \\
\text { flap or loss of vascularization }\end{array}$ \\
\hline $\begin{array}{l}\text { V-Y advancement } \\
\text { flap }\end{array}$ & $\begin{array}{l}\text { Mild to severe stricture at the dentate } \\
\text { line. Middle or high localized } \\
\text { strictures, associated with mucosal } \\
\text { ectropion }\end{array}$ & $\begin{array}{l}\text { The tip of the } \mathrm{V} \text { is subject to } \\
\text { ischemic necrosis }\end{array}$ \\
\hline Diamond flap & $\begin{array}{l}\text { Moderate to severe long stricture, } \\
\text { localized or circumferential stricture } \\
\text { above the dentate line, associated } \\
\text { with mucosal ectropion }\end{array}$ & $\begin{array}{l}\text { A diamond-shaped flap is designed } \\
\text { so that it will cover the intra-anal } \\
\text { portion of the defect. The flap is } \\
\text { mobilized with minimal } \\
\text { undermining to preserve the integrity } \\
\text { of the subcutaneous vascular pedicle }\end{array}$ \\
\hline House flap & $\begin{array}{c}\text { Moderate to severe long } \\
\text { stricture,localized or } \\
\text { circumferential or diffuse, and } \\
\text { stricture above the dentate line, } \\
\text { associated with mucosal ectropion }\end{array}$ & $\begin{array}{l}\text { It allows primary closure of the } \\
\text { donor site and increases anal canal } \\
\text { diameter along its length. Because } \\
\text { of the wide base, it avoids the pitfall } \\
\text { of having a narrow apex present } \\
\text { inside the anal canal that may } \\
\text { become ischemic }\end{array}$ \\
\hline U flap & $\begin{array}{c}\text { Moderate to severe } \\
\text { stricture, localized or } \\
\text { circumferential associated with } \\
\text { mucosal ectropion }\end{array}$ & $\begin{array}{l}\text { This technique is particularly useful } \\
\text { when there is need to excise a } \\
\text { significant area of ectropion. The } \\
\text { donor site is left open }\end{array}$ \\
\hline C flap & $\begin{array}{l}\text { Moderate to severe stricture, } \\
\text { localized or circumferential } \\
\text { associated with mucosal ectropion }\end{array}$ & The donor site is left open \\
\hline Rotational S flap & $\begin{array}{l}\text { High severe stricture, circumferential } \\
\text { or diffuse, associated with mucosal } \\
\text { ectropion }\end{array}$ & $\begin{array}{l}\text { It provides for adequate blood } \\
\text { supply, avoids tension, and can be } \\
\text { performed bilaterally if necessary } \\
\text { for coverage of large areas of skin. } \\
\text { Complex technique: high morbidity } \\
\text { and longer hospital stay }\end{array}$ \\
\hline
\end{tabular}


The operative management of anal stenosis differs according to the length of anal canal affected. Anal stenosis associated with Crohn's disease is treated with dilation with the patient under anesthesia with good results. Severe lower anal canal stenosis is best treated by V$\mathrm{Y}$ anoplasty or a simple sphincterotomy or multiple anal sphincterotomies achieving good result. On the other hand, middle, upper and entire anal canal stenoses are treated effectively by single or multiple internal anal sphincterotomies, or alternatively by advancement flap anoplasty procedures, which was the case in our series as most were post hemorrhoidectomy strictures. This proved correct as stated by Milson \& Mazier who stated that when there is lack of healthy anoderm, this mandates advancement flap anoplasty with the sphincterotomy. ${ }^{3}$

However, the best treatment is prevention, which is achieved by:

$>$ Adequate anorectal surgery by a dedicated surgeon, with delicate tissue handling. $>$ The use of absorbable sutures and minimal resection of tissues. 5

To conclude; House flap anoplasty is simple and can be used to correct many anoderm deficiencies with a high rate of success and patient satisfaction.

\section{References:}

1- Habr-Gama A, Sobrado C, de Araújo S, et al: Surgical treatment of anal stenosis: Assessment of 77 anoplasties. Clinics 2005; 60(1): 17-20.

2- Sentovich S, Falk P, Christensen M, Thorson A, et al: Operative results of house advancement anoplasty. BJS 2008; 83(9): 1242-1244.

3- Milsom J, Mazier P: Classification and management of postsurgical anal stenosis. Surg Gynecol Obstet 1986; 163(1): 60-64. 4- Casadesus D, Villasana L, Diaz H, Chavez M, Sanchez I, et al: Treatment of anal stenosis: A 5-year review. ANZ J Surg 2007; 77( 7): 557-559.

5- Brisinda G, Vanella S, Cadeddu F, Marniga G, Mazzeo P, Brandara F, Maria G: Surgical treatment of anal stenosis. World J Gastroenterol 2009; 15(16): 1921-1928. 6- Christensen M, Pitsch R, Cali R, Blatchford G, Thorson A: "House" advancement pedicle flap for anal stenosis. Diseases of the Colon \& Rectum 2005; 35(2): 201-203. 